\title{
KONSELING MEMENGARUHI PERUBAHAN PERILAKU CALON AKSEPTOR DALAM PEMILIHAN ALAT KONTRASEPSI IUD
}

\author{
Evi Desfauza, Idau Ginting, Elizawarda \\ Jurusan Kebidanan Poltekkes Kemenkes Medan
}

Abstract

Indonesia is a large population of about 215 million people, the fourth largest in the world with quality is still very low, ranks 112 out of 175 in 2003. In 2005 Indonesia's population increased from 219.9 million to 231.3 million in 2009 with a population growth rate of $1.29 \%$ per year. Based on the 2002-2003 IDHS, that TFR Popinsi North Sumatra in the position of numbers: 3, achieving an active participant KB 2006 was $1,187,815$ or $62.06 \%$ of the EFA: 1914002 , and tends hormonal contraceptive options, the pill: $35.37 \%$, $33.15 \%$ whereas injections IUD only $11.63 \%$. The research design using design methods Quasi Experiments with one group before and after intervention. The population is all couples of child 79 people, sampling the accidental the clinic as many as 4,241 people Tuntungan Medan. Sa 2012. Analysis of univariate and bivariate implemented using computer software. The resultaceptive IUD is an average increase of knowledge 11:08, and after counseling about family planning contraceptive 1 ittude 9899 with $S D=11,189 . p=0.00$, and an average $S D=16.87$. $p$-value $=0.00$, mean increase Atitude $\mathrm{S} D=7,305, p=0.005$, Behovior change takes a long time and repeated information, it is expected to midwives and oir own decisions with the right and need further rearch props repea

Keywords : counseling, family planning acceptors, IUD

\section{PENDAHULUAN}

Situasi dan kondisi Indonesia dalam bidang kependudukan, kualitasnya saat ini masih sangat memprihatinkan. Dengan jumlah penduduk yang sangat besar, sekitar 215 juta jiwa atau nomor empat terbesar didunia, tetapi kualitasnya masih sangat rendah. Berdasarkan penilaian UNDP, pada tahun 2003 kualitas sumber daya manusia yang diukur melalui Indeks Pembangunan Manusia (Human Development Index) Indonesia menempati peringkat 112 dari 175 negara di dunia. (Arjoso S, 2005)

Berdasarkan hasil Sensus penduduk tahun 2010 jumlah penduduk Indonesia sebanyak 237.556 .363 jiwa dengan laju pertumbuhan $1,49 \% /$ th atau secara absolut bertambah 4,3 jt/th. Meskipun telah terjadi penurunan pertumbuhan penduduk karena menurunnya angka kelahiran, namun pada periode 2005-2009 jumlah kelahiran di Indonesia masih sekitar 4,3 juta jiwa per tahun. (BKKBN, 2011)

Sejalan dengan meningkatnya pemakaian alat kontrasepsi dan penurunan angka fertilitas, laju pertumbuhan penduduk juga mengalami penurunan, dari $2,34 \%$ per tahun pada kurun 1970-1980 menjadi $1,97 \%$ per tahun pada kurun 1980-1990 dan pada tahun 2010 menjadi 1,49\% per tahun(BKKBN, 2011)

Berdasarkan hasil SDKI 2002-2003, angka kelahiran total (Total Fertility Rate /TFR) pada wanita usia subur miskin diperkirakan 3,0 anak per wanita, sedangkan yang kaya 2,2 per wanita dan di Propinsi Sumatera Utara berada pada posisi angka : 3 , keadaan ini masih tinggi, perlu upaya intensif yang mengarah pada penurunan TFR setiap wanita usia subur menjadi 2,2 per perempuan. (BKKBN, 2011) Pencapaian peserta KB baru kumulatif di Propinsi Sumatera Utara sampai dengan bulan Desember 2006 sebesar 231.310 peserta atau 98,03\% dari perkiraan permintaan masyarakat peserta baru (PPMPB) sebesar 235.970 peserta, dengan rincian per mix kontrasepsi hormonal yaitu Pil 38,57\%, suntikan $40,58 \%$, implant $4,48 \%$ sedangkan pengguna IUD hanya $4,79 \%$ (Bunyamin, 2007)

Berdasarkan laporan BKKBN Propinsi Sumatera Utara di puskesmas Padang Bulan Medan pada bulan November 2010 tercatat dari 8.125 PUS peserta KB aktif sebanyak $3.825(47,08 \%)$ alat kontrasepsi yang digunakan adalah ; IUD $796(21,36 \%)$, MOW $380(10,20 \%)$, kondom $146(3,62)$ Implant $522(14,01$, pil $838(22,48 \%)$, suntik $1.141(28,28)$ hasil cakupan pelayanan $\mathrm{KB} /$ akseptor baru di puskesmas Medan Tuntungan tahun 2011 sebanyak 373 orang dengan rincian sebagai berikut; pil 78 orang $(20.91 \%)$, suntik 81 orang $(21.72 \%)$, IUD 86 orang $(23.06 \%)$, Kondom 32 orang $(8.58 \%)$, implant 71 orang $(19.03 \%)$, dan MOW 25 orang $(6.70 \%)$ dibandingkan dengan data KB Nasional dan provinsi Sumatera Utara IUD menempati urutan ke 3 
Sebagaimana diketahui bahwa kontrasepsi IUD merupakan jenis kontrasepsi non hormonal yang dapat digunakan dalam jangka waktu panjang. Namun kenyataannya saat ini, masyarakat peserta $\mathrm{KB}$ cendrung memilih kontrasepsi hormonal seperti suntikan dan pil KB. Berbeda dengan IUD yang tidak mengandung hormonal, penggunaan suntik dan pil secara terus menerus dapat menimbulkan efek samping, komplikasi yang tidak diharapkan. Selain itu juga dari sisi efisiensi pembiayaan, penggunaan kontrasepsi hormonal lebih mahal jika dibandingkan dengan penggunaan kontrasepsi non hormonal (BKKBN Sumut 2007).

Untuk mencegah peledakan penduduk maka pemerintah memprogramkan untuk melatih tenaga kesehatan di Indonesia sebanyak 35.000 bidan dan 10.000 dokter untuk pemasangan IUD. Di Provinsi Sumatera Utara sudah dilatih sebanyak 2700 bidan dan 1000 dokter

Berdasarkan surat dari kepala BKKBN Propinsi Sumatera Utara nomor 1033/KU-806/1.3/2012 perihal pelayanan IUD pada puncak Bulan Bhakti IBI yang menyatakan masih rendahnya pencapaian Akseptor KB pada tahun 2012 ( masih 22,18\%) untuk melaksanakan pekan IUD pada minggu ke III bulan Juni 2012 untuk memberi pelayanan KB mencapai 100 akseptor IUD per kebupaten/Kota.

Sesuai dengan hasil penelitian yang sudah penulis lakukan tentang Analisis Persepsi Akseptor KB Hormonal tehadap alat kontrasepsi IUD di Wilayah Kerja Puskesmas Padang Bulan Medan dan puskesmas Medan Tuntungan tahun 2011, sebanyak 54,1\% responden mempunyai persepsi negatif terhadap alat kontrasepsi IUD dan hal ini disebabkan karena kurangnya pengetahuan responden tentang alat kontrasepsi IUD sebanyak 73,9\% (Desfauza $\mathbb{E}, \mathrm{dkk}, 2011)$

IUD adalah Suatu alat kontrasepsi yang dimasukkan kedalam rahim terbuat dari plastik halus (Polyethelen) untuk mencegah terjadinya konsepsi atau kehamilan (BKKBN,2003).

Keuntungan memakai alat kontrasepsi IUD banyak sekali diantaranya: memerlukan hanya satu kali motivasi dan pemasangan, tidak ada efek sistemik, dapat mencegah kehamilan dalam jangka panjang, kegagalan yang disebabkan karena kesalahan akseptor tidak banyak, efektifitas tinggi, kesuburan dapat pulih kembali (reversible), dan juga ekonomis (Mochtar, 1998)

Berdasarkan uraian diatas maka penulis tertarik untuk melakukan penelitian pengaruh konseling dalam merubah perlaku caion akseptor tentang IUD demi terwujudnya misi Pembangunan KB Nasional untuk membangun setiap keluarga indonesia untuk memiliki anak Ideal, sehat, berpendidikan, sejahtera, berketahanan dan terpenuhi hak-hak reproduksinya.

\section{METODE PENELITAN}

Penelitian ini dilakukan diwilayah kerja puskesmas Medan Tuntungan kecamatan Medan
Tuntungan, selama 6 bulan Juni s/d November 2012 pengumpulan data dari bulan Juni s/d Oktober 2012

Rancangan penelitian ini adalah quasi eksperimen, dengan design one group before and after intervention, untuk mengetahui perbedaan perilaku calon akseptor $\mathrm{KB}$ sebelum dan setelah dilakukan konseling tentang IUD. Variabel independen adalah perilaku PUS calon akseptor KB (pengetahuan, sikap, dan tindakan) dan variabel dependen adalah pengguna kontrasepsi IUU,

Instrumen penelitian ini pretest menggunakan kuestioner tertutup dan posttes. Instrumen terbuka. Populasi adalah seluruh pasangan usia subur yang tercatat di wilayah kerja puskesmas Medan Tuntungan pada tahun 2011 sebanyak 4.241 orang. Sampel adalah semua ibu yang datang ke puskesmas dan klinik bersalin pada masa interval yang akan menjadi akseptor KB sebanyak 79 responden dengan kriteria inklusi adalah calon akseptor yang bersedia dilakukan konseling dan belum menjadi akseptor KB IUD. Kriteria eksklusi adalah calon akseptor yang bersedia dilakukan konseling dan sudah menjadi akseptor KB IUD

Analisis data dilakukan secara Univariat, Bivariat digunakan untuk mengetahui perbedaan rata-rata sebelum dạn sesudah konseling digunakan uji $t$ dependen sering disebut uji t Pair/Related dengan rumus:

$$
t=\frac{D}{S D \_d / \sqrt{n}}
$$

\section{Hasil penelitian dan Pembahasan}

Gambaran karakteristik responden dapat dilihat pada tabel 1.

Tabel 1. Gambaran Karakteristik Responden Calon Akseptor KB Sebelum dan Sesudah Konseling di Wilayah Kerja Puskesmas Medan Tuntungan tahun 2012

\begin{tabular}{llrr}
\hline No & \multicolumn{1}{c}{$\begin{array}{c}\text { Karakteristik } \\
\text { Responden }\end{array}$} & f $\begin{array}{c}\text { Jumlah } \\
\mathbf{\%}\end{array}$ \\
\hline $\mathbf{1}$ & Pendidikan & 15 & 9,0 \\
& SD & 17 & 1,5 \\
& SLTP & 42 & 3,2 \\
& SLTA & 5 & 6,3 \\
& Perguruan Tinggi & 79 & 100 \\
& Jumlah & & \\
$\mathbf{2}$ & Pekerjaan & 54 & 8,4 \\
& Ibu rumah tangga & 6 & 7,6 \\
& Petani & 15 & 9,0 \\
& Wiraswasta & 4 & 5,1 \\
& PNS/Swasta & 79 & 100 \\
\hline & Jumlah & & \\
\hline
\end{tabular}

Dari tabel diatas dapat diambil kesimpulan sebagian besar responden berpendidikan SLTA yaitu 42 orang $(53,2)$ dan paling sedikit berpendidikan perguruan tinggi dan masih ada yang berpendidikan SD sebanyak 15 orang $(19,0 \%)$ 
Dilihat dari pekerjaan responden mayoritas sebagai ibu rumah tangga sebanyak 54 orang $(68,4 \%)$ dan minoritas sebagai PNS/Swasta yaitu 4 orang $(5,1 \%)$.

Tabel. 2. Distribusi Perilaku Responden Sebelum dan Sesudah Konseling di Wilayah Kerja Puskesmas Medan Tuntungan tahun 2012

\begin{tabular}{ccccc}
\hline \multicolumn{4}{c}{ Puskesmas Medan Tuntungan tahun 2012 } \\
\hline \multirow{2}{*}{ No $\quad$ Perilaku } & \multicolumn{2}{c}{ Pre } & Post Konseling \\
\cline { 2 - 5 } & Konseling & Pot & \\
\cline { 2 - 5 } & F & $\%$ & F & $\%$ \\
\hline
\end{tabular}

Pengetahuan Ressponden

\begin{tabular}{|c|c|c|c|c|}
\hline$<20$ & 4 & 5.06 & & \\
\hline $0-39$ & 21 & 26.58 & 35 & 44,30 \\
\hline $40-59$ & 36 & 45.57 & 11 & 13,92 \\
\hline $60-80$ & 17 & 21.52 & 27 & 34,18 \\
\hline$>80$ & 1 & 1.27 & 6 & 7,59 \\
\hline $\begin{array}{l}\text { Jumlah } \\
\text { Respon }\end{array}$ & 79 & 100 & 79 & 100 \\
\hline $\begin{array}{l}18-34 \\
35-53\end{array}$ & 24 & 30,3 & 5 & 6,33 \\
\hline $\begin{array}{l}35-53 \\
>53\end{array}$ & $\begin{array}{c}52 \\
3\end{array}$ & $\begin{array}{c}65.82 \\
3.80\end{array}$ & $7 \dot{z}$ & 92,41 \\
\hline Jumlah & 79 & 100 & 79 & 100 \\
\hline
\end{tabular}

Alat Kontrasepsi yang dipilih

\begin{tabular}{lcccc} 
Susuk & 7 & 1,27 & 8 & 10,13 \\
Suntik & 51 & 64,56 & 44 & 55,70 \\
Pil & 8 & 10,13 & 8 & 10,13 \\
Kondom & 3 & 12,66 & 2 & 1,27 \\
IUD & 10 & 12,66 & 18 & 22,78 \\
Jumlah & 79 & 100 & 79 & 100 \\
\hline
\end{tabular}

Dari tabel 4.2. dapat dilihat pengetahuan responden sebelum dilakukan konseling hanya sebagian kecil berpengetahuan baik tentang alat kontrasepsi dalam rahim (IUD) yaitu sebanyak 18 orang $(22,77 \%)$

Sesudah dilakukan konseling tentang alat kontrasepsi IUD pengetahuan responden meningkat yang berpengetahuan baik menjadi 33 orang $(41,77 \%)$

Berdasarkan sikap responden sebelum dan sesudah dilakukan konseling mayoritas sikapnya
mendukung

Alat kontrasepsi yang akan digunakan responden sebelum dilakukan konseling responden sebagian kecil responden yang tertarik untuk menggunakan IUD, hanya 10 orang $(12,66 \%)$ yang memilih IUD dan setelah dilakukan konseling tentang IUD responden yang berkeinginan untuk menggunakan IUD sebagai alat kontrasepsi meningkat menjadi 18 orang $(22,78 \%)$
Tabel 3. Distribusi Hasil Pengetahuan Responden Sebelum Dan Sesudah Dilakukan Konseling Pada Calon Akseptor Diwilayah Kerja Puskesmas Tahun 2012

\begin{tabular}{lccccc}
\multicolumn{1}{c}{ Variabel } & Mean & $\begin{array}{c}\text { Standar } \\
\text { Deviasi }\end{array}$ & SE & $\begin{array}{c}\text { P. } \\
\text { value }\end{array}$ & N \\
\hline $\begin{array}{l}\text { Pengetahuan } \\
\text { - Pretest }\end{array}$ & 42.56 & 15.616 & 1.757 & 0,00 & 79 \\
- Postest & 53.63 & 18.462 & 2.077 & & \\
\hline Sikap & & & & & \\
- Pretest & 37.91 & 7.696 & .866 & .000 & 79 \\
-Postest & 47.81 & 10.635 & 1.197 & & \\
\hline Tindakan & & & & & \\
- Pretest & 4.11 & 8.006 & .901 & .000 & 79 \\
-Postest & 6.51 & 10.112 & 1.138 & & \\
\hline
\end{tabular}

\section{B.1. Perbedaan pengetahuan sebelum dan sesudah konseling}

Dari hasil penelitian yang telah dilakukan didapat nilai rata-rata pretest 42,56 dan posttest 53,63 dan terjadi peningkatan pengetahuan 11.08 berarti ada perbedaan pengetahuan antara sebelum dan sesudah dilakukan konseling tentang alat kontrasepsi IUD,

Penelitian ini sejalan dengan hasil penelitian yang dilakukan oleh Kusumaningtiyas DPH yaitu Ada hubungan antara tingkat pengetahuan wanita usia subur tentang pemilihan alat kontrasepsi IUD setelah diberikan konseling KB yang dilakukan di kelurahan Kartoharjo kecamatan Nganjuk kabupaten Nganjuk Jawa Timur $(\mathrm{P}=0,000$ dan correlation coefficient 0,481$)$, sesuai juga dengan Teori Stimulus-Organisme-Respons (SOR) mengasumsi bahwa penyebab terjadinya perubahan perilaku tergantung kepada kualitas rangsang (stimulus) yang berkomunikasi dengan organisme. Artinya kualitas dari sumber komunikasi (sources) misalnya kredibilitas, gaya berbicara sangat menentukan keberhasilan perubahan perilaku seseorang, kelompok atau masyarakat. Menurut pendapat Hosland, et al (1953) mengatakan bahwa proses perubahan perilaku pada hakekatnya sama dengan proses belajar yaitu dengan pemberian informasi akan meningkatkan pengetahuan responden. Perubahan perilaku dengan cara ini memakan waktu lama, tetapi perubahan yang dicapai bersifat langgeng karena didasari oleh kesadaran mereka sendiri (bukan karena paksaan).

Peningkatan dari pengetahuan juga tergantung kepada kualitas dari sumber komunikasi (sources) misalnya kredibilitas, gaya berbicara sangat menentukan keberhasilan perubahan pengetahuan seseorang.

Dari hasil penelitian terdapat $58,22 \%$ responden perpengetahuan kurang setelah dilakukan konseling hal ini disebabkan pendidikan responden lebih dari $40 \%$ berpendidikan rendah (SD dan SMP) sesuai dengan pendapat (Arikunto, 2002) tingkat pendidikan juga merupakan salah satu faktor yang mempengaruhi persepsi seseorang untuk lebih mudah menerima ide-ide dan teknologi baru, dapat mendukung atau mempengaruhi tingkat pengetahuan seseorang, dan taraf pendidikan yang rendah selalu bergandengan dengan informasi dan pengetahuan yang terbatas, makin tinggi pendidikan semakin tinggi pula pemahaman seseorang terhadap 
Infinesesi yang didapat dan pengetahuan pun akan semakin Heits.

ID. Perbedaan sikap responden sebelum dan sesudah konseling

Dari hasil penelitian yang telah dilakukan ertfrpat perbedaan yang signifikan antara sikap monden tentang alat kontrasepsi IUD sebelum dilakukan ikunseling dengan sesudah dilakukan konseling. dengan pethedaan -9.899 dengan standar deviasi 11.189, nilai $I=1,00$,

Sikap merupakan keadaan dalam diri manusia vang menggerakkan untuk menanggapi alat kontrasepsi IID, selain itu sikap juga memberikan kesiapan untuk merespon yang sifatnya positif atau negative tentang alat Inumrasepsi IUD. Dari penelitian yang dilakukan sebelum Ian sesudah dilakukan konseling sikap responden sudah magyoritas mendukung terhadap alat kontrasepsi, hasil penelitian tidak sejalan dengan teori yaitu sikap mendukung yang dilandasi dengan pengetahuan yang baik, menurut B.F. Skinner (dalam, Azwar 2005) pembentukan Silap dipengaruhi Pengalaman pribadi, karena sikap akan Enih mudah terbentuk apabila pengalaman pribadi tersebut melibatkan faktor emosional. Adanya pengaruh orang lain yang dianggap penting. pada umumnya, individu bersikap Inomformis atau searah dengan sikap orang orang yang Itranggapnya penting. Kecenderungan ini antara lain Imotivasi oleh keinginan untuk berafiliasi dan keinginan unth menghindari konflik dengan orang yang dianggap perting tersebut. Media massa sebagai sarana komunikasi, hethagai media massa seperti televisi, radio, mempunyai pengaruh besar dalam pembentukan opini dan kepercayaan arang Adanya informasi baru mengenai sesuatu hal memberikan landasan kognitif baru bagi terbentuknya shap terhadap hal tersebut. Pesan-pesan sugestif yang Illawa informasi tersebut, apabila cukup kuat, akan memberi dasar afektif dalam mempersepsikan dan menilai sesuatu hal sehingga terbentuklah arah sikap tertentu.

Institusi Pendidikan dan Agama. Sebagai suatu sistem, institusi pendidikan dan agama mempunyai pengaruh kuat thlam pembentukan sikap dikarenakan keduanya meletakkan dasar pengertian dan konsep moral dalam diri incividu.

3. Perbedaan tindakan responden tentang alat kontrasepsi dalam rahim (IUD) sebelum dan sesudah dilakukan konseling

Dari penelitian yang sudah dilakukan ada perbedaan yang signifikan antara tindakan responden tentang alat kontrasepsi IUD sebelum dilakukan konseling dengan sesudah dilakukan konseling. adanya peningkatan milai pretest dan posttest sebesar 2.392 dengan standar deviasi 7.305 , nilai $p=0,005$,

Dari 79 responden yang diteliti, yang berkeinginan untuk menggunakan IUD hanya 10 orang (12,66) peningkatan dalam pemilihan alat kontrasepsi IUI) hanya $10,12 \%$. Penelitian ini sesuai dengan penelitian Prochaska, dari promosi kesehatan/program pencegahan penyakit dirancang untuk komunitas skala kecil (minoritas) pada tahap tindakan. Dia memperkirakan di antara orang- orang tersebut yang perokok pada tahun 1985 hampir $70 \%$ tidak siap pada tahap tindakan.

Menurut pendapat Kurt Lewin (1970) bahwa perilaku manusia adalah suatu keadaan yang seimbang antara kekuatan-kekuatan pendorong (driving forces) dan kekuatan-kekuatan penahan (restrining forces). Perilaku ini dapat berubah apabila terjadi ketidak seimbangan antara kedua kekuatan tersebut didalam diri seseorang.

Dari penelitian penulis terdahulu 54,1 \% responden mempunyai persepsi negatif tentang IUD, setelah dilakukan konseling $93,68 \%$ responden mempunyai sikap mendukung tentang alat kontrasepsi IUD tetapi tidak dilanjutkan dengan tindakan, hal ini disebabkan banyak faktor penghambat calon akseptor menggunakan alat kontrasepsi IUD antara lain dilarang suami karena suami merasa tidak puas, dan pengalaman masa lalu setelah pemasangan terjadi perdarahan, dan pengalaman orang lain dan masih ada yang mempunyai persepsi yang negatif tentang IUD.

Menurut Pavlov perubahan perilaku terjadi karena adanya latihan dan pengulangan kebiasaan dan kemauan bertindak.

\section{Kesimpulan}

Berdasarkan hasil analisis dan pembahasan hasil penelitian, dapat diambil kesimpulan mengenai pengartih konseling terhadap perubahan perilaku calon akseptor KB menggunakan IUD di wilayah kerja Puskesmas Medan Tuntungan

Setelah dilakukan uji secara univariat didapat adanya peningkatan pengetahuan, sikap dan tindakan responden setelah dilakukan konseling tentang alat kontrasepsi IUD.

Berdasarkan uji bivariat terdapat perbedaan yang signifikan perilaku calon akseptor KB sebelum dilakukan konseling dengan sesudah dilakukan konseling perubahan yang sangat berarti adalah peningkatan rata-rata pada pengetahuan dengan nilai 11.08 , tetapi $77,22 \%$ responden tidak siap sampai dengan tindakan untuk menggunakan alat kontrasepsi IUD. hal ini disebabkan oleh dilarang suami, pengalaman masa lalu dan pengalaman orang lain

\section{A. Saran}

Berdasarkan kesimpulan diatas perubahan yang terjadi pada tindakan masih belum memuaskan maka diharapkan

1. Pada petugas kesehatan terutama bidan yang bertugas di puskesmas atau klinik bersalin atau praktek swasta untuk tidak bosan-bosannya memberikan konseling karena perubahan perilaku tidak hanya dilakukan satu kali melainkan berulangulang, sebaiknya memberikan konseling tentang KB diberikan lebih dini yaitu pada saat ibu melakukan ANC. Memberikan konseling dengan melibatkan suami untuk memberikan pengertian yang benar tentang alat kontrasepsi termasuk, keuntungan, kerugian, indikasi dan kontra indikasi serta efek samping dari masing alat kontrasepsi. Kemudian ditunjukkan kepada mereka baik secara langsung ataupun tidak langsung, misalnya melalui film, 
slide, photo, gambar, atau cerita bagaimana cara kerja. Hal ini diharapkan akan bisa membangkitkan keinginan mereka untuk menggunakan alat kontrasepsi yang aman berperilaku hidup sehat. Cara ini memang memakan waktu lama untuk bisa dilihat hasilnya, tetapi sekali berhasil. maka ia akan bertahan lebih lama dibandingkan dengan cara cara lainnya.

2. Pada peneliti Salanjutnya

Perlu untuk menindak lanjuti penelitian ini pada subjek yang berbeda yaitu pengaruh konseling tentang IUD pada suami

\section{DAFTAR PUSTAKA}

Arjoso S ; Kebijakan Program Keluarga Berencana Nasional

Bidan Delima Petunjuk Pelaksanaan Kegiatan Momentum Bulan Bhakti KB-IBI Propinsi Sumatera Utara tahun 2007

BKKBN, 2004 Pedoman Kewenangan Wajib dan Standar Pelayanan Minimal Bidang Keluarga Berencana -2011 Rakerda Pembangunan Kependudukan dan Keluarga Berencana Tahun 2011
Bunyamin, perkembangan Program KB Nasional Tahun 2006 Propinsi Sumatera Utara

Desfauza, E, dkk, 2011; Analisis Persepsi Akseptor KB Hormonal tehadap alat kontrasepsi IUD di Wilayah Kerja Puskesmas Padang Bulan Medan tahun 2011 Laporan penelitian

Kusumaningtiyas DPH, 2009; Hubungan Antara Tingkat Pengetahuan Wanita Usia Subur Tentang Konseling KB dengan Pemilihan Alat Kontrasepsi IUD Di Kelurahan Kartoharjo Kecamatan Nganjuk Kabupaten Nganjuk Jawa Timur, Laporan penelitian

Maramis W F, 2006; Ilmu Perilaku Dalam Pelayanan Kesehatan Airlangga University Press .

MNH. (2002) Modul pelatihan keterampilan KIP/K

Mochtar, R. 1998. Sinopsis Obstetri Jilid 2. Jakarta : EGC.

Notoatmodjo, S, 2007, Promosi Kesehatan \& Ilmu Perilaku Penerbit Rineka Cipta

Sudjana., 2003. Metoda Statistika Penerbit Tarsito Bandung 